Forthcoming, Estreicher \& Radice, Beyond Elite Law: Access to Civil Justice for Americans of Average

Means (Cambridge University Press)

\title{
Life in the Law-Thick World: The Legal Resource Landscape for Ordinary Americans
}

\author{
Gillian K. Hadfield \& \\ Jamie Heine
}

Ours is a law-thick world. ${ }^{1}$ Most advanced market democracies are pervaded by laws and rules that structure social and economic relationships. Ordinary people, businesses, and institutions alike interact with rules and legal principles both formally and informally on a daily basis: the "defining circumstances" $^{2}$ of everyday life-employment, consumer transactions, family dynamics, financial matters, and more-all have legal dimensions. The United States has a particularly complex and expansive civil legal system, partly because of America's uniquely adversarial approach to law and policy. ${ }^{3}$ Navigating the web of complex rules that comprises our social and economic framework requires legal resources-legal information, advice, documents, representation; the rule of law presumes access to the civil legal system and legal resources. But what does the landscape of legal resources look like for ordinary Americans? Are we living in an environment that is thick with law but thin on legal resources?

Unfortunately, we know very little about the legal resource landscape, especially when it comes to services for Americans of average means. We don't have a national federally-funded research agency like the National Institutes of Health, which distributes over $\$ 30$ billion in 50,000 grants annually to

\footnotetext{
${ }^{1}$ Gillian K. Hadfield, Higher Demand, Lower Supply? A Comparative Assessment of the Legal Resource Landscape for Ordinary Americans, 37 FORDHAM URBAN LAW JOURNAL 129 (2009). This chapter is an updated and expanded 2 Pascoe Pleasence, Alexy Buck, Nigel Balmer, Aoife O'Grady, Hazel Genn \& Marisol Smith, CAUSES OF ACTION: CIVIL LAW AND SOCIAL WELFARE 13 (2004).

${ }^{3}$ Robert A. Kagan, AdVersarial Legalism: The American Way of LAW (2001).
} 
medical researchers who collect, analyze, and are often required to share, data on disease, medical procedures and the impact of interventions. ${ }^{4}$ We don't have the legal equivalent of public health departments, tracking the legal health of communities. We don't have the legal analogs of specialists in epidemiology, studying the causes and patterns of legal problems in communities. While legal academia produces thousands of articles published in law reviews each year, such research typically focuses on law itself, not the public or markets the law serves. The major well-funded and regularly conducted studies on the legal system that do exist focus on the market for corporate legal services. ${ }^{5}$ As a result, systematic efforts to collect data about the health of legal systems for ordinary individuals are few and far between.

Of the small number of studies analyzing the performance of the legal system for non-corporate clients almost all focus on the delivery of legal services to the poor as a form of charity or welfare assistance. While obviously of high significance, assessing only this segment of legal markets is a bit like assessing the performance of the U.S. health care system by asking only how well Medicaid and free clinics work. It treats the issues of access and cost for citizens as if they were entirely questions of the appropriate levels of charity (pro bono) and welfare spending. But the vitality of our legal systems is a matter of great importance throughout the income distribution. We all make decisions on a daily basis that rely on our understanding of the legal rules that structure our relationships with family, neighbors, schools, manufacturers, governments and more.

Casually, most of us in the legal profession know that the bulk of civil legal services are ultimately provided not to ordinary people but to corporations. The 1995 Chicago Lawyers' Surveyone of the very few systematic efforts to assess the allocation of legal work across client sectorsestimated that only $29 \%$ of Chicago lawyers' efforts went to providing legal services to individuals or

\footnotetext{
${ }^{4}$ NIH Budget, NAT'L INSTS. OF HEALTH, http://www.nih.gov/about/budget.htm (last visited Sept. 9, 2013).

${ }^{5}$ See, e.g., Citi Private Bank, Annual SURVEY of LAW FIRM FInANCIAL PERFORMANCE (conducted annually for the past 25 years); Altman Weil, LAW FIRMS IN TRANSITION SURVEY (conducted annually for the past five years); ALM Legal Intelligence, SURVEY OF LAW FIRM ECONOMICS (conducted annually for the past forty years).
} 
small businesses. ${ }^{6}$ The "personal plight" category-comprised of civil rights, criminal defense, divorce, family, and personal injury plaintiff work-accounted for a mere $16 \%$ of total effort. ${ }^{7}$ Both of these figures indicated drops relative to 1975 (from $40 \%$ and $21 \%$ respectively) ${ }^{8}$; the survey has not been updated but in all likelihood there have been comparable drops in the past twenty years as well.

In this chapter we pull together the small and disconnected bits of available data on the legal resources available to ordinary Americans -- the best we can do to shed some light on the performance of the U.S. legal markets serving non-corporate clients. We draw on some data from other countries to put our limited U.S. data into perspective. The goal is to try to get a handle on the health of the legal markets serving ordinary citizens as a whole. Our results suggest that, while the U.S. has a robust legal system with nearly twice as many lawyers per capita as most other countries, ordinary Americans have very little access to reasonably-priced legal help in navigating that system.

We begin with a "macro" view, comparing the resources at an aggregate level that are devoted to the legal system in the U.S. as compared with other countries. Here we find evidence of a surprising fact: although public expenditure, legal aid, numbers of judges and numbers of lawyers are comparable (or high) on a per capita basis, the much greater volume of cases in the U.S. implies that the U.S. devotes many fewer resources to supporting the legal system on a per case basis. That is, Americans choose or have no choice but to go through court-based processes at much higher rates, but compared to other countries, there are fewer public dollars, judges and even lawyers available to them when they do so. We then turn to a "micro" view, reviewing the available studies that track individual legal needs and the frequency with which individuals choose (or have no choice but) to represent themselves in court, comparing studies conducted at the national and state levels in the U.S. with studies carried out in comparably rich legal settings.

\footnotetext{
6 John P. Heinz, Edward O. Laumann, Robert L. Nelson \& Ethan Michelson, The Changing Character of Lawyers' Work: Chicago in 1975 and 1995, 32 LAW \& Soc'Y REV. 752, 765 (1998).

${ }^{7}$ Id.

${ }^{8} / d$.
} 
We identify here a troubling indication that Americans are led to 'lump' their legal problems and do nothing about them at higher rates than is the case in these other countries. Looking closely at these studies suggests that one reason might be that Americans have fewer places to turn for legal help: environments in which people have more open regulatory systems that allow a wider variety of professionals to assist people with legal problems - not just lawyers, as is the case in the U.S.-appear to be ones in which people are significantly less likely to do nothing when troubles emerge. That is important: ignoring legal problems is likely to cause more problems. Moreover, both ignoring legal problems and muddling through without legal help undermines our confidence that the complex legal rules and entitlements we have put in place are, in fact, accomplishing the objectives they are designed to achieve.

The Macro View: Aggregate Legal Resources

The legal services industry in the U.S. is a multi-billion dollar industry and accounts for just under half of the revenue generated by the global legal services industry. ${ }^{9}$ In 2010 , legal services provided by private practitioners generated $\$ 204$ billion ${ }^{10}$ in gross domestic product in the United States; total receipts for law firms totaled $\$ 237$ billion. ${ }^{11}$ Neither figure counts legal services provided within corporations, government, legal aid providers or other private associations, which account for $18 \%$ of all lawyers. ${ }^{12}$ If we 'gross up' these numbers to value the contributions of lawyers in these other settings, the total size of the legal services sector in the United States is thus roughly $\$ 249$ billion in GDP terms and $\$ 289$ billion in expenditures on legal services. By way of comparison, in 2010 GDP in educational services was $\$ 166$ billion; health care services $\$ 1.1$ trillion; agriculture $\$ 158$ billion; food, beverage and

\footnotetext{
${ }^{9}$ U.S. International Trade Commission, Recent Trends in U.S. Services Trade: 2011 Annual Report, at 7.2 (July 2011).

${ }^{10}$ U.S. Bureau of Economic Analysis, Gross Domestic Product by Industry 2010 (Value Added by Industry Table).

${ }^{11}$ U.S. Census Bureau, Service Annual Survey 2010 Current Business Reports, t.6.3 (2012).

${ }^{12}$ American Bar Foundation, The Lawyer Statistical Report 2013(2005 data). 75\% work in private practice, 4\% are inactive or retired, $3 \%$ serve in the judiciary and $1 \%$ in legal academia.
} 
tobacco products $\$ 219$ billion; securities, commodities contracts, and investments $\$ 181$ billion; and computer system design and related services $\$ 183$ billion.

While the U.S. legal services market is massive, ordinary citizens consume well under half of these resources. Of the roughly $\$ 289$ billion spent on legal services, approximately $34 \%$ is consumed by individuals as part of personal consumption expenditures $(\$ 97.7$ billion in 2010$) .^{13}$ Another $1 \%{ }^{14}(\$ 2.89$ billion) can be attributed to services provided by legal aid lawyers and public defenders. Some share, but it is not possible to easily say how much, of the expenditure on government lawyers other than legal aid and public defenders may be attributable to providing services to individual Americans; in some sense, one could classify all of those expenditures (approximately $\$ 23$ billion or $8 \%$ ) as being on behalf of ordinary citizens. But clearly much of this expenditure is of little personal use to individuals. This suggests that at most $42 \%$ of legal services, and more reasonably a bit more than $35 \%$, are serving the needs of individual citizens as opposed to corporations and businesses.

These figures comport with data from the only U.S. study of the allocation of legal effort across different types of matters and clients. As we noted earlier, the Chicago Lawyers' Survey estimated that in 1995 Chicago lawyers devoted $29 \%$ of total effort to services for individual or small business clients. ${ }^{15}$ These figures probably understate the total share of all legal services statewide and nationwide because of the concentration of corporate law firms in this major financial center. ${ }^{16}$ These numbers are in line with the census-based estimate above that approximately $35 \%$ of all legal services in the U.S. are available to individuals as opposed to corporations or governments.

\footnotetext{
${ }^{13}$ U.S. Bureau of Economic Analysis, Personal Consumption Expenditure Underlying Detail Tables, t.2.4.5U (Personal Consumption Expenditures by Type of Product), 2010.

${ }^{14}$ ABA, Lawyer Demographics 2013.

15 John P. Heinz, Edward O. Laumann, Robert L. Nelson and Ethan Michelson "The Changing Character of Lawyers' Work: Chicago in 1975 and 1995" 32 Law and Society Review 752 (1998).

${ }^{16}$ Correcting for this and looking province-wide in Ontario, one of us (Hadfield) together with Ronit Dinovitzer estimated that in 1998 Ontario lawyers devoted $42 \%$ of their effort in total to services for individual as opposed to corporate clients; in Toronto, a city of comparable size and financial significance as Chicago, the figure was $31 \%$ We also estimated that an additional $10 \%$ worked in government. (Unpublished data on file with authors. )
} 
In the abstract and in isolation it is difficult to say whether this share of legal services devoted to ordinary citizens' interests is 'enough.' In theory, if ordinary citizens demanded more legal services, the legal services market could supply them; and, of course, the ordinary citizen benefits from the operation of a well-regulated and efficient market and thus from the availability of legal services to corporate entities as well. To put further perspective on these numbers, we have therefore calculated what the personal share of the legal services market represents in terms of available legal effort and how this has changed over the last few decades.

In 1990, expenditures by households on legal services totaled $\$ 82.9$ billion in 2012 dollars. At that time, the average hourly rate for lawyers in small firms (less than 20 lawyers, where we find most of the lawyers providing services to individuals) was roughly $\$ 209$ in 2012 dollars. ${ }^{17}$ Based on the total U.S. population for that year, this implies an average of 1.6 hours per person for the year or 4.3 hours per average household. ${ }^{18}$ Conducting the same calculation for 2012 (total expenditures of $\$ 105.1$ billion and an average hourly rate of $\$ 263$ for small-firm lawyers, both in 2012 dollars ${ }^{19}$ ) yields an average of 1.3 hours per person or 3.0 hours per household, a decline of $30 \%{ }^{20}$

How does this compare with the availability of legal resources for those who live in comparably or even less law-thick environments around the globe? We do not have comparable data on personal expenditures on legal services and average hourly rates in other countries with which to do similar calculations. But we do have comparative data on expenditures in the legal system as a whole for a

\footnotetext{
${ }^{17}$ This figure is based on Altman-Weil data, which is a self-selected proprietary survey and subject to substantial error. It is, however, the only quasi-systematic data we are aware of for hourly rates nationally in this year. We took a straight (unweighted) average of rates for those with 4-5 years' experience and those with 11-20 years' experience for firms with less than 9 and 9-20 lawyers and inflated based on the CPI.

${ }^{18}$ Based on population estimate for 1990 of $253,491,263$ and a household estimate of $91,900,900$.

${ }^{19}$ This figure is based on Altman-Weil data for 2012, taking a straight average of rates for equity and non-equity partners and associates in firms of less than 9 and 10-24 lawyers.

${ }^{20}$ Based on population estimate for 2012 of $313,873,685$ and household estimate of $132,802,859$. http://quickfacts.census.gov/qfd/states/00000.html
} 
large set of European countries ${ }^{21}$ and it is to these data that we turn for (again, rough) estimates of the availability of legal resources in the economy as a whole for ordinary citizens to address their relationships with and through the legal system. ${ }^{22}$

Table 1 provides data for the U.S. and a selection of European and Anglo-American countries showing total population, total public expenditure on courts, public prosecution and legal aid, total numbers of criminal and civil cases, and total numbers of judges and lawyers. These data should be read carefully, keeping in mind the potential for differences in the categories of what is counted and how data requests in the European survey were interpreted. ${ }^{23}$ U.S. criminal cases includes serious crimes and misdemeanors but excludes the 56.3 million traffic cases that also appear in state courts; the European data cover both serious crimes and misdemeanors but purport to exclude administrative offences and those processed by the police such as minor traffic offences. Civil cases include all noncriminal filings in the U.S. state and federal courts but exclude filings before administrative agencies that are not appealed to a court.

Table 1: Total Resources and Cases

\section{\begin{tabular}{|ll|ll|l|l|l|l|}
\hline Country & Population & Public & Legal & Criminal & Civil & Judges & Lawyers
\end{tabular}}

\footnotetext{
${ }^{21}$ European Commission for the Efficiency of Justice, European Judicial Systems: Edition 2012 (data 2010): Efficiency and Quality of Justice. In all data reported below euros are converted to U.S. dollars at an exchange rate of $\$ 1=€ 0.785$.

${ }^{22}$ Justice Earl Johnson Jr. first drew attention to just how low the U.S. expenditure on civil legal aid was relative to other advanced market democracies. Justice Earl Johnson Jr., Equal Access to Justice: Comparing Access to Justice in the United States and Other Industrial Democracies, 24 Ford. Intl. L. J. S83 (2000).

${ }^{23}$ It is particularly important to note that the data reported here differ substantially from data reported in Christian Wollschlager, Exploring Global Landscapes of Litigation Rates, in (eds.) Soziologie des Rechts: Festschrift fur Erhard Blankenburg (Jurgen Brand \& Dieter Strempel eds. 1998). Wollschlager reports many more cases per capita for Germany than the data here; this is because he includes summary debt collections that are excluded here. Although Germany has by far the highest number of cases per capita in his data, and the U.S. ranks $5^{\text {th }}$ just ahead of the U.K. and Hungary, he notes that if the summary debt cases are excluded, the U.S. is the highest per capita after Israel. (p. 583). In addition Erhard Blankenburg, The Infrastructure for Avoiding Civil Litigation: Comparing Cultures of Legal Behavior in The Netherlands and West Germany, 28 L. \& Soc. Rev. 789 (1994), suggests that The Netherlands has a much lower and Germany a much higher number of cases than is reported here. We were unable to determine from the published studies what might account for these differences; one possibility is change over time. Blankenburg appears to be drawing on data from the 1980 s.
} 


\begin{tabular}{|c|c|c|c|c|c|c|c|}
\hline \multicolumn{2}{|c|}{} & \multicolumn{2}{|c|}{$\begin{array}{c}\text { Expenditure } \\
\text { on Courts, } \\
\text { Prosecutors } \\
\text { \& Legal Aid } \\
\text { (\$\$ M) }\end{array}$} & $\begin{array}{c}\text { Cases } \\
\text { (M) }\end{array}$ & $\begin{array}{c}\text { Cases } \\
\text { (M) }\end{array}$ & \\
\hline U.S. & $313,914,040$ & 56 & 3,700 & 20.8 & 28.6 & 31,930 & $1,268,011$ \\
\hline France & $65,026,885$ & 5 & 460 & 1.1 & 2.3 & 6,945 & 51,758 \\
\hline Germany & $81,751,602$ & 11 & 487 & 1.2 & 5.8 & 19,831 & 155,679 \\
\hline Hungary & $9,986,000$ & 0.5 & 0.4 & 0.3 & 0.7 & 2,891 & 12,099 \\
\hline Netherlands & $16,665,799$ & 2.5 & 457 & 0.4 & 1.5 & 2,530 & 16,728 \\
\hline $\begin{array}{c}\text { Poland } \\
\text { Polat }\end{array}$ & $38,200,000$ & 2.2 & 30 & 1.1 & 6.2 & 10,625 & 29,469 \\
\hline $\begin{array}{c}\text { U.K. } \\
\text { (England \& } \\
\text { Wales) }\end{array}$ & $55,200,000$ & 5.7 & 3,211 & 1.9 & 2 & 4,913 & 165,128 \\
\hline
\end{tabular}

Sources: ABA Commission on Ethics 20/20 Working Group on Alternative Business Structures, Issue Paper Concerning Alternative Business Structures (2011); European Commission for the Efficiency of Justice, Report on European Judicial Systems (2012, 2010 data; includes contested and uncontested matters but excludes administrative matters and land registry); U.S. Census Bureau; Bureau of Justice Statistics, Justice Expenditure and Employment Extracts 2010 (July 1, 2013); Examining the Work of State Courts: An Analysis of 2010 State Court Caseloads (Court Statistics Project 2012); Federal Judicial Center Annual Report of the Director: Judicial Business of the United States Courts (2012); American Bar Foundation Lawyer Demographics (2013); Alan W. Houseman, Civil Legal Aid in the United States: An Update for 2011 (April 2011) (estimate includes public and private charitable sources).

The count of judges for the U.S. includes all full-time federal and state judicial officers including magistrates, but does not include judicial officers sitting pro tem (temporary judges) or administrative law judges in state or federal governments; in the European data, we include full-time professional judges and exclude part-time professional judges and lay-judges. The count of lawyers includes both advocates and legal advisors who are members of a bar. This is a particularly difficult number to compare. While the count of lawyers who belong to a bar association in the U.S. is a very good measure of the availability of legal advice and representation-as only these people can provide these servicesin most other countries bar membership is not co-extensive with an authorization to provide services. As we discuss in more detail, below, in both the U.K. and the Netherlands, for example, anyone may provide legal advice, although only bar members are counted here. In many European countries lawyers 
who are employed by a company, government or organization need not-in some cases may not-be a member of the bar and thus are not counted. With these caveats in mind, Table 2 calculates the availability of legal resources per person and per case in the system.

Table 2 presents a stark picture. While U.S. public expenditure per capita on courts, judges, prosecutors and legal aid is the highest among this set of both advanced and transitioning countries, when we take into account the vastly higher numbers of cases in the U.S. court system yes, public expenditure per case is significantly lower than in other advanced democracies; only relative to the amounts spent in emerging market democracies that are still seeking to build the rule of law in their countries does the U.S. expenditure level look high. Publicly financed legal aid per capita in the U.S. is lower than in the Netherlands and the U.K. ${ }^{24}$ and higher than in other advanced and emerging democracies; but legal aid per case is well below that expended in other advanced democracies except Germany, exceeding only the low levels available in Hungary and Poland. Legally-trained personnel also appear to be much less available in the U.S. when we take into account the number of cases in the U.S. The number of judges per capita in the U.S. is significantly lower than in Germany, Poland and Hungary, and comparable to the levels in France and the Netherlands and U.K But again the intensity of legal demand in the U.S., as measured by number of

\section{Table 2: Comparative Resources Per Person and Per Case}

\begin{tabular}{|c|c|c|c|c|c|c|c|c|c|c|c|}
\hline Country & $\begin{array}{c}\text { Public } \\
\text { spend } \\
\text { per } \\
\text { capita }\end{array}$ & $\begin{array}{c}\text { Public } \\
\text { spend per } \\
\text { case }\end{array}$ & $\begin{array}{l}\text { Legal } \\
\text { Aid } \\
\text { per } \\
\text { capita }\end{array}$ & $\begin{array}{l}\text { Legal } \\
\text { aid } \\
\text { per } \\
\text { case }\end{array}$ & $\begin{array}{c}\text { Judges } \\
\text { per } \\
100,000 \\
\text { persons }\end{array}$ & $\begin{array}{c}\text { Judges } \\
\text { per } \\
100,000 \\
\text { cases }\end{array}$ & $\begin{array}{c}\text { Lawyers } \\
\text { per } \\
100,000 \\
\text { persons }\end{array}$ & $\begin{array}{c}\text { Lawyers } \\
\text { per } \\
100,000 \\
\text { cases }\end{array}$ & $\begin{array}{c}\text { Criminal } \\
\text { Cases per } \\
100,000 \\
\text { persons }\end{array}$ & $\begin{array}{c}\text { Civil } \\
\text { Cases } \\
\text { per } \\
100,000 \\
\text { persons }\end{array}$ & $\begin{array}{c}\text { Total } \\
\text { Cases } \\
\text { per } \\
100,000 \\
\text { persons }\end{array}$ \\
\hline
\end{tabular}

\footnotetext{
${ }^{24}$ The U.K. recently announced significant cuts to its legal aid budget: $£ 320$ million per year by $2014-15$ and an additional $£ 220$ million per year by 2018-19. Ministry of Justice, Transforming Legal Aid: Delivering a More Credible and Efficient System, Consultation Paper CP 14/2013, at 5. The numbers above do not reflect any cuts. These cuts would be a $15 \%$ reduction in aid per case and per 100,000 people, though the number of cases could decline if less legal aid is available.
} 


\begin{tabular}{|c|c|c|c|c|c|c|c|c|c|c|c|}
\hline U.S. & $\$ 178$ & $\$ 1,136$ & $\$ 12$ & $\$ 75$ & 10 & 65 & 404 & 2567 & 6626 & 9111 & 15,737 \\
\hline France & $\$ 77$ & $\$ 1,471$ & $\$ 7$ & $\$ 135$ & 11 & 204 & 80 & 1522 & 1692 & 3537 & 5229 \\
\hline Germany & $\$ 135$ & $\$ 1,571$ & $\$ 6$ & $\$ 70$ & 24 & 283 & 190 & 2224 & 1468 & 7095 & 8563 \\
\hline Hungary & $\$ 50$ & $\$ 500$ & $\$ 0$ & $\$ 0$ & 29 & 289 & 121 & 1210 & 3004 & 7010 & 10014 \\
\hline Netherlands & $\$ 150$ & $\$ 1,316$ & $\$ 27$ & $\$ 241$ & 15 & 133 & 100 & 880 & 2400 & 9000 & 11401 \\
\hline $\begin{array}{c}\text { Poland } \\
\begin{array}{c}\text { U.K. } \\
\text { (England \& } \\
\text { Wales) }\end{array}\end{array}$ & $\$ 103$ & $\$ 1,462$ & $\$ 58$ & $\$ 823$ & 9 & 126 & 299 & 4234 & 3442 & 3623 & 7065 \\
\hline
\end{tabular}

cases, reveals that per case there are far fewer judges available in the U.S. than in any of these European countries: roughly half as many as in the U.K. and the Netherlands, roughly a third of those available in France and less than one-quarter of those in Germany and Hungary. Lawyers do not clearly make up all of the difference: while there are more lawyers, counted as bar members per capita in the U.S. than in this set of comparison countries, again the numbers per case reveal that the U.K., with significantly more judges per case, also has more than one and a half times as many lawyers per case. The U.S numbers per case look in Table 2 to be higher than in France, Hungary, the Netherlands and Polandbut European bar members do not have the complete monopoly on provision of legal services that they do in the U.S. and so the European numbers are (perhaps significantly) understated. Moreover, given that we are ultimately interested in legal services available to individuals as opposed to business, the relatively large corporate sector in the U.S. and the fact that many in-house corporate lawyers in European countries are not counted as members of the bar also suggests that the U.S. figure is an overstatement of the availability of lawyer assistance to ordinary Americans.

Not all the lawyers in these counts, of course, are delivering litigation-related services such as those that would be demanded by individuals (and businesses - the data here do not separate out client types) in court cases. But we can interpret the number of cases in the courts as an indicator of the level of overall 
demand in the economy for legal inputs for the planning and management of social and economic relationships. There is no clear or singular interpretation of the substantially higher number of cases per capita in the U.S.: this could be because of more law, greater willingness to use courts as opposed to alternative means for dispute resolution and/or higher levels of unmet needs for ex ante legal advice, planning and dispute resolution assistance. But this is precisely what makes the strikingly low levels of legal resources so salient: U.S. socio-economic life is, as Robert Kagan ${ }^{25}$ has emphasized, substantially more reliant on law and legal management of relationships and yet the U.S. devotes far fewer resources to providing the legal services needed to translate law on the books into law on the ground.

\section{The Micro View: Legal Needs}

We turn now to a view closer to that ground. Few studies have attempted to quantify the legal needs ordinary Americans face. Existing data suggest at least half of all households face a legal problem each year and those households who face legal problems average several per year. These studies likely undercount the extent of legal needs faced by ordinary people because they focus on erupted legal problems, but exclude instances where legal information and advice could aid in planning conduct and avoiding or mitigating legal problems up front. This section explores the legal needs of ordinary Americans and how Americans respond to those needs. What we find suggests that while Americans face legal needs at rates comparable to those faced by people in other countries, Americans are more likely to take no action to resolve these problems. When they do take action, they do so with fewer legal resources available to them: the expenditure data we reviewed in the last section imply that the average household secures an average of less than half an hour of legal assistance per year with legal

${ }^{25}$ Robert A. Kagan, Adversarial Legalism: The American Way of LAW (2001). 
problems and what studies we have of this phenomenon suggest that Americans represent themselves in court more often than do people in other countries.

1. U.S. Civil Legal Needs and the Availability of Legal Help

Civil legal needs surveys can help us get a better sense of people's demand for legal services and their experiences as participants in the legal system. In 1993 the American Bar Association (ABA) conducted a study assessing the legal needs of the poor (defined as those living at or below $125 \%$ of the poverty line), and those with moderate income (those with incomes falling in the middle $60 \%$ of the income distribution). ${ }^{26}$ The study defined "legal needs" as problems or disputes households had encountered, such as sub-standard housing, job loss or divorce, and that could potentially be addressed through the civil legal system. With few exceptions (review of documents for a real estate transaction, for example) the focus of the study was on ex post dispute resolution and the nature of the legal assistance that might be offered.

The study found that approximately $51 \%$ of households ( $47 \%$ of poor households and $52 \%$ of moderate-income households) had experienced one or more legal needs in the previous year. The average number of problems experienced by those with legal needs was two. Of those with legal needs, $38 \%$ of the poor sought assistance from a third-party for resolution of the problem, $29 \%$ from a specifically legal third-party such as a lawyer (21\%) or other legal/judicial actor or entity (8\%). ${ }^{27}$ Thirtyeight percent did nothing to resolve their problem ${ }^{28}$, a course of action that has come to be called "lumping it" in the literature. ${ }^{29}$ Among moderate-income households, assistance from a third-party was

\footnotetext{
${ }^{26}$ ABA, Legal Needs And Civil Justice: A Survey of Americans, Major Findings from the Comprehensive Legal NeEds Study *7 (1994). In 1993, the top household income in this group was $\$ 60,000$, approximately $\$ 97,000$ in 2013 dollars. Id. Speculations on the Limits of Legal Change 9 LAW AND SOCIETY REVIEW 95 (1974).
} 
sought for $51 \%$ of problems, $39 \%$ from a specifically legal source (lawyers $28 \%$, other legal/judicial $12 \%$ ), and $26 \%$ of moderate-income households lumped their problems. ${ }^{30}$

There has been no national study of legal needs in the U.S. in the two decades since this ABA study was published. State-level surveys have been conducted and they paint a largely similar picture. Table 1 summarizes the findings of 17 state legal needs surveys. Twelve ${ }^{31}$ of the surveys report legal needs experienced by low-income individuals or households. Georgia, Montana, Nevada, and Oregon surveyed households of low- and moderate- income; Arizona included households of all incomes. The list of problems provided to respondents was relatively consistent across states.

\footnotetext{
${ }^{30} / d$.

${ }^{31}$ New Jersey conducted a small-sample survey of higher income households as well but these results are not generalizable to the larger population. We report only the lower-income New Jersey results. In addition, our research identified studies done in Arkansas, Idaho, Minnesota, and Nebraska. The published reports from these studies, however, do not provide enough detail to develop statistics comparable to those shown for other states in Table 1.
} 
Table 3: State Legal Needs Surveys

\begin{tabular}{|c|c|c|c|c|c|}
\hline State & Year & $\begin{array}{l}\text { Prevalence of } \\
\text { Legal Needs } \\
\text { (\% of } \\
\text { households } \\
\text { unless noted) }\end{array}$ & $\begin{array}{c}\text { Average } \\
\text { Number of } \\
\text { Legal Needs } \\
\text { (respondents } \\
\text { with at least } \\
\text { one } \\
\text { problem) }\end{array}$ & $\begin{array}{l}\text { No steps taken } \\
\text { to resolve } \\
\text { problem }\end{array}$ & $\begin{array}{l}\text { Contact with } \\
\text { lawyer or legal } \\
\text { institution } \\
\text { (\% of problems } \\
\text { unless noted) }\end{array}$ \\
\hline Alabama $^{+}$ & 2006 & $48 \%$ & 3.6 & $20 \%$ & $16 \%$ \\
\hline Arizonan $^{\wedge}$ & 2007 & $32 \%$ (individuals) & - & $24 \%$ & $16 \%$ \\
\hline Connecticut $^{+}$ & 2002 & $65 \%$ & 4.1 & $33 \%$ & $10 \%$ \\
\hline Georgia $^{ \pm}$ & $2007-2008$ & $62 \%$ & 4.6 & $28 \%$ & $8 \%$ \\
\hline Illinois $^{+}$ & 2004 & $49 \%$ & 3.5 & - & $16 \%$ \\
\hline Massachusetts $^{+}$ & 2002 & $67 \%$ & 3.6 & $45 \%$ & $\begin{array}{c}<19 \% \text { (HHs, at } \\
\text { least one problem) }\end{array}$ \\
\hline Montana $^{ \pm}$ & 2004 & - & $>3.5$ & - & $16 \%$ \\
\hline Nevada $^{ \pm}$ & 2007 & $68 \%$ & 2.4 & - & $\begin{array}{c}9 \% \text { (HHs, all } \\
\text { problems) } \\
20 \% \text { (HHs, at least } \\
\text { one problem) }\end{array}$ \\
\hline New Jersey ${ }^{+}$ & 2007 & $33 \%$ (individuals) & 2.3 & $23 \%$ & $14 \%$ \\
\hline New York ${ }^{+}$ & 2010 & $47 \%$ & $>2.0$ & $>56 \%$ & $\begin{array}{c}17 \% \text { (HHs, at least } \\
\text { one problem) }\end{array}$ \\
\hline Oregon $^{ \pm}$ & $1999-2000$ & $82 \%$ & 3.9 & - & $18 \%$ \\
\hline Tennessee $^{+}$ & 2003 & $70 \%$ & 4.7 & $\begin{array}{l}25 \% \text { (biggest } \\
\text { problems) }\end{array}$ & $\begin{array}{c}24 \%-40 \% \text { (biggest } \\
\text { problems) }\end{array}$ \\
\hline Utah $^{+}$ & $2005-2006$ & $68 \%$ & 1.3 & - & $13 \%(\mathrm{HHs})$ \\
\hline Vermont $^{+}$ & 2001 & $50 \%$ (est.) & 2.2 & $30 \%$ & $9 \%$ \\
\hline Virginia $^{+}$ & $2005-2006$ & $55 \%$ & 3.4 & $42 \%$ & $\begin{array}{c}<32 \% \text { (HHs, at least } \\
\text { one problem) }\end{array}$ \\
\hline Washington $^{+}$ & $2002-2003$ & $87 \%$ & 3.3 & - & $12 \%$ \\
\hline Wisconsin $^{+}$ & 2006 & $45 \%$ & 2.1 & - & $\begin{array}{c}12 \% \text { (HHs, all } \\
\text { problems) } \\
27 \% \text { (HHs, at least } \\
\text { one problem) }\end{array}$ \\
\hline
\end{tabular}

${ }^{+}$Low-income

All-income

¿Low- and Moderate-Income

Sources: State Legal Needs Studies, available at

http://www.nlada.org/Civil/Civil_SPAN/SPAN_Library/document_list?topics=000055\&list_title=State+Legal+Needs +Studies\%3A+Reports\&start=1.

Georgia: Report excludes from 'no action' those who took no action but reported satisfaction with result (48\%); results in chart are estimated to adjust to include those for comparability with other studies. 
Massachusetts: Percentage contacting lawyer is upper bound because not corrected for those who contacted more than one type of legal provider (private lawyers, legal aid).

Montana: Average number of legal needs is across all households, including those with no legal needs.

New Jersey: Measure is incidence, not prevalence-includes only new legal needs in given year-does not include problems pending from prior years; no action includes problems not yet resolved; higher income sample analyzed in full report but not generalizable to full population.

New York: Percent taking no action is upper bound because $56 \%$ reported taking no action on any problem.

Nevada: Average number of legal needs is reported as average number of categories in which problems occurred; actual number of legal problems may be higher.

Tennessee: Average number of legal needs is estimate based on average number of problems in categories reported.

Vermont: Excludes households without phones.

Virginia: Percentage contacting lawyer is upper bound because not corrected for those who contacted more than one type of legal provider (private lawyers, legal clinic, legal aid).

Wisconsin: Average number of legal needs is reported as average number of categories in which problems occurred; actual number of legal problems may be higher.

The data in Table 3 paint an even grimmer picture of the legal environment facing ordinary Americans than the ABA study. It is clear from this collection of state studies that the incidence of legal problems is at least the $50 \%$ of households identified by the ABA study; the fact that numbers at least this high are consistently found in almost all state surveys supports the reliability of this estimate. A straight average across those states providing estimates at the household level suggests roughly $60 \%$ of American households are dealing with a legal problem at any one time. ${ }^{32}$ Moreover, a rough calculation taking a straight average across the state studies suggests the average number of problems in households experiencing problems has increased from the two found by the ABA to three. The rates at which poor Americans lump their problems seems about as high in these studies as in the ABA study: averaging across the studies limited to low-income households, the rate is about $36 \%$, compared with $38 \%$; the two studies that included higher-income households and reported data on this show the same average rate (26\%) as the ABA study. Finally, it appears that the 1993 ABA estimate of the likelihood that Americans receive help from a lawyer when dealing with legal problems is high relative to what the states are finding in these studies conducted a decade or so later. Again a rough calculation taking a

\footnotetext{
${ }^{32}$ Although most of the state surveys focus on the poor, the 1993 ABA study found little difference in the prevalence of problems between poor and moderate income households; if anything, moderate income households reported more problems.
} 
straight average across the states that present a clear number on this (that is, excluding MA, NV, NY, TN, UT, VA, and WI), suggests that fewer than $13 \%$ of poor and $15 \%$ of moderate-income Americans have contact with a lawyer or other legal provider; this is substantially lower than the $29 \%$ (poor) and $39 \%$ (moderate income) rates found by the ABA.

A drop in legal help is consistent with the census data on expenditures on personal legal services that we reviewed earlier. ${ }^{33}$ Using the rough estimates of hourly rates for lawyers in small firms that we calculated there, the 1993 ABA estimate that the average household experienced one legal problem a year $^{34}$ for 1990 and a straight average of the number of problems (2) per household reported by the state surveys $^{35}$ for 2012, we estimate that in 1990 American households were able on average to draw on approximately four hours of legal time to address a legal problem and in 2012 they were able to draw on significantly less than half that amount: approximately an hour and a half.

An hour and a half of legal help per problem is a very low number, and yet it is still an overestimate. The legal needs surveys only ask about erupted civil problems - a dispute over employment or a foreclosure or a denial of health care or the risk of injury to or a diminished relationship with a child-and these are the only problems we included in our estimate above. Our count of problems excludes the demand for legal assistance with criminal matters where public defender help is unforthcoming or inadequate. It excludes the demand for legal assistance before problems arise, such as legal advice in assessing a complex mortgage offer or employment options or insurance coverage or the potential for conduct to influence custody of a child. If for every dispute-

\footnotetext{
${ }^{33}$ See supra p. 6.

${ }^{34}$ This is based on the estimate that half of households experience problems and the average number of problems in these households is two; this averages to one per household across all households.

${ }^{35}$ These surveys are of problems facing poor households but the ABA Legal Needs Survey suggests that the rate for poor households is not significantly different from that for moderate-income households. Table 1 reports average problems per household with a problem and the percentage of households with problems; we have calculated the average number of across all households for each state and taken a straight average. We have excluded the data for New Jersey from this calculation because it is based on problems per individual, as well as the data for Montana because the survey does not report the percentage of households experiencing problems.
} 
related need there is an ex ante advice related need (as appears to be the case for large corporations ${ }^{36}$ ), this implies that today the average household is able to draw on less than an hour's worth of legal advice or assistance in dealing with the points at which their everyday lives intersect with the legal system in such a way as to require them to assess legal rights or consequences.

The low rate at which Americans obtain legal assistance with their legal problems is also indicated by the information we have about publicly financed legal aid. According to the $A B A$, only $1 \%$ of American lawyers are either legal aid lawyers or public defenders ${ }^{37}$; the number of legal aid attorneys providing civil legal services was calculated by the Legal Services Corporation to be 7,931 , just over onehalf of one percent of all U.S. lawyers. ${ }^{38}$ Moreover, the availability of legal aid in practice is characterized by "fragmentation and inequality" and "geography as destiny." ${ }^{39}$ Many who seek free legal assistance are turned away. The Legal Services Corporation (LSC), the only federally funded legal aid agency, reported in 2009 that, as a result of resource limitations, LSC-funded programs were only able to serve half of the poor who sought assistance. ${ }^{40}$

What do Americans do when they do not obtain help from lawyers with their legal problems? The U.S. civil legal needs surveys indicate that a large fraction of them-roughly a third-do nothing at all; the state surveys indicate that in some settings the number among the poor is closer to one half. There can be many reasons people take no action: they may not think the effort is worth it, they may not know what to do, they may have nowhere affordable to turn, they may be too overwhelmed by this

\footnotetext{
${ }^{36}$ Mark Chandler, General Counsel of Cisco Systems Inc. reports that total legal expenditures in his company are $.3 \%$ of company revenue with .16\% coming from nonlitigation expenses. http://www.law.com/jsp/ihc/PubArticlelHC.jsp?id=1188291741577.

${ }^{37}$ ABA Lawyer Demographics (2013), available at http://www.americanbar.org/content/dam/aba/migrated/marketresearch/PublicDocuments/lawyer_demographi CS_2012_revised.authcheckdam.pdf.

38 Legal Servs. Corp., Documenting the Justice Gap in America: The CurRent Unmet Civil Legal NeEdS OF LoW-INCOME AMERICANS 20-21 (2009), available at http://www.Isc.gov/JusticeGap.pdf.

${ }^{39}$ Rebecca L. Sandefur and Aaron C. Smyth Access Across America 2011: First Report of the Civil Justice Infrastructure Mapping Project (October 7, 2011).

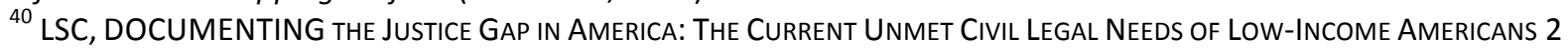
(2009), available at http://www.Isc.gov/JusticeGap.pdf.
} 
and other problems to act. Even with the caveat that not all decisions to do nothing are evidence of a failure of the legal system to provide adequate assistance, ${ }^{41}$ however, the rates at which Americans lump their problems is troubling. The legal-needs surveys consistently identify serious legal issues, where failure to obtain any legal advice generates significant risk that outcomes will not be the ones judged by the law to be fair and appropriate-people losing homes they are entitled to keep, being unpaid when they are entitled to payment, or losing jobs on wrongful grounds; children put at risk or deprived of parental contact, legislated benefits or adequate health care. Moreover, failure to act on legal problems can also breed more problems. Several researchers have found that legal problems tend to occur in clusters, with initial problems triggering others. ${ }^{42}$ The loss of a job or a failure to collect on amounts owed under a contract can lead to failures to pay rent or meet mortgage or other debt payments; financial stress can lead to marital stress and relationship breakdown; relationship breakdown can lead to employment or financial problems. Failing to act on legal problems may only lead to more legal problems-perhaps partly as a consequence of the failure to discover what taking action can accomplish. The person who responds to not being paid by going to small claims court, for example, discovers how that process works; they learn a bit more about the law; and they learn a bit more about themselves. This can be of benefit to them personally and to their communities when they are the ones to whom others turn for advice. Failing to do anything about half or more of these problems is clearly evidence of a large gap between what we think are the legal rules in our communities and people's actual experiences in facing their legal needs. While Americans on average

\footnotetext{
${ }^{41}$ See, e.g., Herbert M. Kritzer, To Lawyer or Not to Lawyer: Is that the Question?, 5 J. LEG. STUD. 875 (2008) (arguing based on empirical evidence that the decision to obtain a lawyer is explained by several variables and that not all those who can afford to hire a lawyer choose to do so).

${ }^{42}$ Currie analyzes the phenomenon of trigger problems, which lead to a cascade of other difficulties. He also emphasizes the momentum of legal difficulties, estimating in his Canadian study that vulnerability to additional problems increases with the number of problems: the probability of a second problem for someone experiencing one is $32 \%$; the probability of a third for someone facing two is $39 \%$; the probability of a sixth for someone facing five (a phenomenon experienced by $8 \%$ of his sample) is $41 \%$. Ab Currie, THE LEGAL Problems Of EVERYDAY LIFE: THE Nature, Extent And Consequences of Justiciable Problems Experienced by CANAdians *43-44 (2007).
} 
encounter as many as two legal problems each year, their actual experiences with the legal system are quite thin.

In some cases people choose, or have no choice, but to become involved with courts: the problem may be too serious to be ignored and may require judicial orders-for child custody or bankruptcy, for example-or a person may be sued (for collection, divorce, foreclosure, probate, etc.) and forced to deal with the legal system. The numbers above indicate that when Americans do interact with the court system, they do so with little legal help. The ABA data may mask this phenomenon-they count as legal help contact with judicial institutions but this includes those who do not seek out judicial help but rather are drawn into legal processes and may not find any of it to be legally helpful; moreover, court personnel in the U.S. cannot give litigants legal advice as they respond to summonses or participate in hearings and there is only so much judges can do without risking the loss of neutrality. Indeed, it is judges-under pressure to help the hapless - who are the most deeply aware of the crisis of unrepresented litigants in their courtrooms.

The annual Judicial Business report of the U.S. Courts provides information on the number of pro se ${ }^{43}$ filings in U.S. federal district courts. In 2012 roughly $28 \%$ of all filings in U.S. district courts were by pro se litigants. Roughly $65 \%$ of these were filed by prisoners challenging prison conditions or civil rights. Of filings by non-prisoners, $12 \%$ were filed by pro se litigants. ${ }^{44}$ To put this in perspectiverecognizing that much of the litigation in federal district courts involves businesses and other organizations enforcing contracts or responding to regulation-social security, civil rights and labor cases make up about $7 \%$ of the caseload in federal district courts; torts account for less than $1 \%$, are rarely filed without a (contingency fee) lawyer and frequently are filed by corporate plaintiffs. This

\footnotetext{
${ }^{43}$ The literature on pro se litigants uses "pro se," "pro per" (California), "self-represented," "unrepresented," and "litigant in person" interchangeably. All are used to indicate a litigant who does not have an attorney appearing on his or her behalf in court or conducting his or her litigation.

${ }^{44}$ U.S. Federal Courts, Judicial Business of the United States Courts 2012, Table C-13. Although the methodology is unclear, it appears that this only counts cases with a pro se filing party and does not include pro se defendants.
} 
suggests a significant portion of ordinary individuals in federal district court are pro se. A review of

federal bankruptcy courts - which handle approximately 1.5 million cases a year, five times as many as federal district courts -indicates that in 2011 approximately 9\% of bankruptcy petitions were pro se. The figure reaches as high as $27 \%$ in high-filing districts such as the central district of California. ${ }^{45}$

The vast majority of U.S. litigation, however, occurs in state courts-approximately $95 \%$. Here the rates of self-representation are much higher, even in general civil filings, a category that includes a large share of corporate, government, and organizational litigants ${ }^{46}$ who invariably have attorney representation. ${ }^{47}$ A 2004 New Hampshire study (2001 data) found that one party is self-represented in 48\% of general civil cases in the state. ${ }^{48}$ A 2005 study of all types of cases in Woodbury County, lowa found that $58 \%$ of cases have a self-represented litigant. ${ }^{49}$ A 2004 California study found that $16 \%$ of petitioners at filing are self-represented in general civil matters. ${ }^{50}$ The California number underestimates, probably substantially, the level of self-representation in general civil litigation because it does not include defendants; nor does it reflect the rate of representation throughout the case or at disposition (many petitioners may choose to file a case while represented, but do not maintain representation throughout).

45 96\% of bankruptcy filings in 2011-2012 were non-business. Judicial Business of the U.S. Courts, Table F-2 (2012). A review of pro se debtors in bankruptcy court in Massachusetts also found that $96 \%$ of cases filed in 1997 were non-business or consumer filings, of which roughly $6 \%$ were pro se. Boston Bar Association Task Force on Unrepresented Litigants, Report on Pro Se Litigation (1998) at 31 (citing National Consumer Law Center, SelfRepresentation in the Bankruptcy Court: The Massachusetts Experience). http://www.bostonbar.org/prs/reports/unrepresented0898.pdf

${ }^{46}$ Recall, for example, the Chicago Lawyers Study which showed that in 1995 only $29 \%$ of legal work was done for personal rather than corporate, organizational or government clients, and only $16 \%$ in personal plight cases which are the matters we expect to see in court.

${ }^{47}$ Roland v California Men's Colony 506 U.S. 194, 201-202 (1993).

${ }^{48}$ State of New Hampshire Judicial Branch, Challenge to Justice: A Report on Self-Represented Litigants in New Hampshire Courts (January 2004).

${ }^{49}$ Report of the Joint lowa Judges Association and lowa State Bar Association Task Force on Pro Se Litigation (May $18,2005)$. The study reports statistics for the Woodbury County district court (state trial level) from a random sampling of schedules from the week of June 7, 2004.

50 Judicial Council of California, Task Force on Self-Represented Litigants, Statewide Action Plan for Serving SelfRepresented Litigants (2004). The California study is based on judicial officer and court staff estimates as well as data from the Judicial Branch Statistical Information System. 
More dramatic evidence of the rate at which ordinary Americans deal with courts without legal help is provided by studies that focus on the types of cases that involve matters that individuals generally cannot ignore or where they are brought in as defendants. Studies of domestic relations and housing cases, for example, consistently reveal very high levels of self-representation. Nationwide, in a study of 16 large urban trial courts in 1991-1992, the National Center on State Courts found that $72 \%$ of domestic relations cases had at least one self-represented party and in $18 \%$ of cases both parties were self-represented. ${ }^{51}$ State-by-state studies confirm the national trend. In 1991, the ABA sponsored the first major study on self-represented litigants in domestic relations cases, conducted in Maricopa County, Arizona. The study found that the percentage of domestic relations cases involving a selfrepresented litigant rose from $24 \%$ in 1980 to $47 \%$ in 1985 to $88 \%$ in $1991 .^{52}$ Both parties were selfrepresented in $52 \%$ of these cases. ${ }^{53}$ Subsequently, numerous state or local studies have been conducted. The Washington study found that from 1995 to 2001, pro se litigants were involved in $80 \%$ of paternity cases and $95 \%$ of domestic violence petitions. ${ }^{54}$ A California study of child support cases found that neither parent was represented in $65 \%$ of cases in 2005 , though this was a decrease from $2001 .^{55}$ The New Hampshire study reported that nearly $70 \%$ of domestic relations cases in state trial courts have one pro se party and $97 \%$ of domestic violence cases had one pro se party. ${ }^{56}$ A Washington study found that from 1995 to 2001, pro se litigants were involved in $80 \%$ of paternity cases and $95 \%$ of

\footnotetext{
${ }^{51}$ Stephan Landsman, Pro Se Litigation, 8 Ann. Rev. L. \& Soc. Sci. 231, 239 (2012) (citing John Goerdt, Divorce Courts: Case Management, Case Characteristics, and the Pace of Litigation in 16 Urban Jurisdictions (1992)).

52 John M. Graecen, Self-Represented Litigants and Court and Legal Services Responses to Their Needs: What We Know, prepared for the Center for Families, Children \& the Courts California Administrative Office of the Courts (undated) (citing Bruce Sales, Connie Beck \&Richard Haan, Is Self-Representation a Reasonable Alternative to Attorney Representation in Divorce Cases? St. L. Univ. L. J. (1993). Available at http://www.courts.ca.gov/partners/documents/SRLwhatweknow.pdf ${ }^{53}$ Boston Bar Association Task Force on Unrepresented Litigants, Report on Pro Se Litigation, 1 (citing Sales, Beck \& Haan, supra).

54 Judicial Services Division Administrative Office of the Courts, An Analysis of Pro Se Litigants in Washington State 1995-2000 (2001), t.1.

55 Judicial Council of California, Review of Statewide Uniform Child Support Guideline 2005, at 52 (2006).

${ }^{56}$ New Hampshire Supreme Court Task Force on Self-Representation, Challenge to Justice: A Report on SelfRepresented Litigants in New Hampshire Courts, 2, 9 (Jan. 2004).
} 
domestic violence petitions. ${ }^{57}$ A Utah study found that $83 \%$ of divorce cases and $87 \%$ of protective order cases had at least one self-represented litigant. ${ }^{58}$ An eight-week study in Florida in 1999 revealed that $65 \%$ of domestic relations cases began with at least one self-represented party, which grew to $85 \%$ in Miami by the end of the case. ${ }^{59}$ A 1997 Boston Bar Association study found that $69 \%$ of cases in Probate and Family Court in several counties in Massachusetts had at least one unrepresented party. ${ }^{60}$ A 2010 New York study found that 97\% of parents in New York City and 95\% of parents outside New York City are unrepresented in child support cases. ${ }^{61} 99 \%$ of tenants in New York City are unrepresented in eviction cases, $99 \%$ of borrowers in New York City are unrepresented in consumer credit cases and $44 \%$ of homeowners are unrepresented in foreclosure cases throughout New York state. ${ }^{62}$ The Utah study found that $98 \%$ of evictions cases have a self-represented litigant. ${ }^{63}$ The New Hampshire study found that tenants were unrepresented in $90 \%$ of landlord-tenant cases. The Boston Bar Association report found that $79 \%$ of litigants in the Northeast Housing Court were unrepresented in 1997; with 50\% of landlords and $92 \%$ of tenants in summary process actions being unrepresented. ${ }^{64}$ The Boston Housing Court found that in 1996 90\% of tenants were unrepresented in summary process eviction actions. $^{65}$

\footnotetext{
57 Judicial Services Division Administrative Office of the Courts, An Analysis of Pro Se Litigants in Washington State 1995-2000 (2001), t.1.

${ }^{58}$ Committee on Resources for Self-Represented Parties, Strategic Planning Initiative Report to the Judicial Council (Utah, July 2006) at 5.

59 John M. Graecen, Self-Represented Litigants and Court and Legal Services Responses to Their Needs: What We Know, prepared for the Center for Families, Children \& the Courts California Administrative Office of the Courts, at 7 (citing Office of the Florida State Court Administrator, Report to the Florida Legislature on Family Court Self-Help Programs (1999)).

${ }^{60}$ Boston Bar Association Task Force on Unrepresented Litigants, Report on Pro Se Litigation, 8.

${ }^{61}$ The Task Force to Expand Access to Civil Legal Services in New York, Report to the Chief Judge of the State of New York (November 2010).

62 The Task Force to Expand Access to Civil Legal Services in New York, Report to the Chief Judge of the State of New York (November 2010)

${ }^{63}$ Committee on Resources for Self-Represented Parties, Strategic Planning Initiative Report to the Judicial Council (Utah, July 2006), at 5.

${ }^{64}$ Boston Bar Association Task Force on Unrepresented Litigants, Report on Pro Se Litigation, 15.

${ }^{65}$ Id. at 16.
} 
These statistics indicate that in some of life's most important defining circumstances selfrepresentation is by far the norm. Together with the U.S. legal needs surveys, the data on legal expenditures and the fraction of lawyers in the U.S. who provide legal aid services, a clear picture emerges: the great majority of ordinary Americans navigate the law-thick world without legal help. This is in stark contrast to complex commercial and tort litigation. For instance, the Washington study found that only in 2-3\% of tort and commercial cases involve self-represented litigants. Similarly, a 1995 Bureau of Justice Statistics report examining 45 trial courts found that only $3 \%$ of tort cases involve a self-represented litigant. ${ }^{66}$

\section{Comparisons with other countries}

In this section, we look at comparable data on civil legal needs and pro se representation in other advanced market democracies. Again the data are incomplete and difficult to evaluate but we see nonetheless evidence of significant differences, differences that we believe reflect the thin nature of the landscape of resources available to ordinary Americans dealing with the legal world.

Since the 1993 ABA study, legal needs surveys have been conducted in at least fifteen countries. ${ }^{67}$ The gold standard for these surveys was developed by Hazel Genn in England in $1996 .{ }^{68}$ Genn's methodology involved face-to-face interviews, presenting individuals with a series of cards listing types of problems-which were not identified as "legal" problems but which were "justiciable" in the sense that they were potentially resolvable using legal means. This methodology, with refinements, has since been used in several countries, and has been administered multiple times in England and Wales.

\footnotetext{
66 Judicial Services Division Administrative Office of the Courts, An Analysis of Pro Se Litigants in Washington State 1995-2000 (2001); Steven K. Smith, Carol J. DeFrances, Patrick A. Langan \& John Goerdt, Tort Cases in Large Counties, Civil Justice Survey of State Courts 1992, 2 (1995).

${ }^{67}$ For a comprehensive review of these surveys see Pascoe Pleasence, Nigel J. Balmer \& Rebecca L. Sandefur, PATHS TO JUSTICE: A PAST, PRESENT AND FUTURE ROADMAP (2013).

68 Hazel Genn, Paths to Justice: What People Do and Think About Going to LaW (1999).
} 
First a caution: surveys differ substantially across different jurisdictions and the results are not directly comparable. Most country studies survey all income levels; the ABA surveyed only the bottom $80 \%$ of the income distribution and most of the state studies focus only on poor households. Some studies ask whether anyone in the household has experienced a problem; others ask only the respondent about their problems. Some studies ask about problems in the last year-like most U.S. studies do-but some ask about problems in the last three or five years. This could increase the rate of problem reporting, although this does not follow as obviously as one might think: many problems are multi-year problems and, as at least one study has shown, people tend to remember and report the same number whether asked about one year or a longer period. ${ }^{69}$ Studies differ in terms of whether they include a signal of the interest of the researchers in specifically "legal" problems: the original ABA study did not but some do. There is evidence that people do not always characterize their problems as "legal" even if a solution might at least in part be found through legal processes. The 2010 New York study, for example, first asked people if they had experienced "legal problems" in the past year; $94 \%$ said "no."70 Researchers then asked if people had experienced any of a list of specifically identified problems which clearly have legal dimensions-such as problems with child support, foreclosure, eviction, denial of benefits, job discrimination and so on. Forty-seven percent reported having at least one such problem. ${ }^{71}$

Studies that include the reference to "legal" problems may therefore underreport them. Some studies expressly ask people about problems that were difficult to solve; others (like the ABA study) do not screen for triviality upfront, although they may (like the ABA study) frame some problem categories as asking about a "major," "serious," or "important" problem. This may not have as big an effect as one

\footnotetext{
${ }^{69}$ Pascoe Pleasence, Nigel J. Balmer \& Stian Reimers 2010, Comparing Apples and Oranges: Methodological Issues Affecting the Comparative Analysis of the Public's Experience of Legal Problems (undated) Presentation, University College of London (on file with authors)

${ }^{70}$ The Task Force to Expand Access to Civil Legal Services in New York, Report to the Chief Judge of the State of New York, Appendices 16 (2010).

${ }^{71}$ Id. at 17.
} 
might think; people tend to forget ${ }^{72}$ or leave out less important problems. Surveys can differ somewhat in the list of problems they ask about-some (e.g., ABA 1993) ask about small business difficulties, for example, but most do not. Different survey techniques-in person, on the phone, online-can also influence responses. People may be more willing to report some types of problems online than in person; they may be more inclined to censor out less important issues when face-to-face. Internet and (usually landline) phone methods too can influence the mix of respondents, making it harder to reach people without internet connections or who do not use landlines. ${ }^{73}$

With these caveats in mind, however, evaluating the U.S. studies in light of studies from other countries is nonetheless illuminating about the legal landscape facing Americans. Table 3 presents data from the 1993 ABA study and rough averages from the combined state studies conducted between 2000 and 2010 together with results from a set of other comparable countries. The data indicate that the rate at which Americans report experiencing justiciable problems is comparable to the rate in other countries. Certainly there is nothing to suggest here that the U.S. studies are out of line with experiences in comparable market democracies with high per capita income and highly developed legal systems. And there is no reason to think the U.S. number is inflated, relative to other studies, by trivial or inconsequential matters. The U.S. study asked about the broadest range of problems (although it lacked a catch-all "other" category that several other studies use to compensate for a more restricted list of specific examples) but it also frequently used language such as "difficult" or "important" to qualify the type of problem in which the surveyor was interested.

\section{Table 4: Actions taken by those reporting legal problem}

\footnotetext{
${ }^{72}$ Pascoe Pleasence, Nigel J. Balmer \& Tania Tam Failure to Recall: Indications from the English and Welsh Civil and Social Justice Survey of the Relative Severity and Incidence of Civil Justice Problems, in 12 Access to Justice: Sociology of Crime, Law and Deviance Vol. 12, 43-65 (Rebecca L. Sandefur ed. 2009).

${ }^{73}$ For an extended analysis of differences in survey methodology across national studies, see Paths to Justice, supra note 68 .
} 


\begin{tabular}{|c|c|c|c|c|c|c|}
\hline $\begin{array}{l}\text { Country } \\
\text { (year of data } \\
\text { collection) }\end{array}$ & $\begin{array}{c}\text { Prevalence } \\
\text { (reference } \\
\text { period, yrs) } \\
\text { [reference group] }\end{array}$ & $\begin{array}{l}\text { Took } \\
\text { no } \\
\text { action }\end{array}$ & $\begin{array}{l}\text { Dealt with } \\
\text { problem } \\
\text { alone or } \\
\text { informally }\end{array}$ & $\begin{array}{c}\text { Contact } \\
\text { with } \\
\text { lawyer }\end{array}$ & $\begin{array}{c}\text { Contact } \\
\text { with } \\
\text { other } \\
\text { legal } \\
\text { provider } \\
\text { or judicial } \\
\text { institution }\end{array}$ & $\begin{array}{c}\text { Contact } \\
\text { with } \\
\text { provider } \\
\text { not } \\
\text { authorized } \\
\text { to provide } \\
\text { legal help }\end{array}$ \\
\hline $\begin{array}{c}\text { US National } \\
\text { Poor + } \\
\text { Middle } \\
\text { Income } \\
\text { (1993) }\end{array}$ & $\begin{array}{c}51 \% \\
(1)[\mathrm{hh}]\end{array}$ & $29 \%$ & $23 \%$ & $26 \%$ & $11 \%$ & $11 \%$ \\
\hline $\begin{array}{c}\text { US State } \\
\text { Average } \\
(2000-2010)\end{array}$ & $62 \%(1)[\mathrm{hh}]$ & $33 \%$ & -- & $14 \%$ & -- & -- \\
\hline $\begin{array}{c}\text { Australia } \\
\text { (2008) }\end{array}$ & $\begin{array}{c}50 \% \\
(1)[\text { ind] }\end{array}$ & $18 \%$ & $31 \%$ & $16 \%$ & $13 \%$ & $36 \%$ \\
\hline $\begin{array}{l}\text { Canada } \\
(2006)\end{array}$ & $\begin{array}{c}45 \% \\
\text { (3)[ind/partner] }\end{array}$ & $22 \%$ & $44 \%$ & $9 \%$ & -- & $22 \%$ \\
\hline $\begin{array}{c}\text { England \& } \\
\text { Wales } \\
(1997-98)\end{array}$ & $\begin{array}{c}40 \% \\
\text { (5)[ind/partner] }\end{array}$ & $5 \%$ & $35 \%$ & $27 \%$ & $33 \%$ & $\mathrm{n} / \mathrm{a}^{*}$ \\
\hline $\begin{array}{l}\text { England and } \\
\text { Wales (2010) }\end{array}$ & $\begin{array}{c}33 \% \\
(1.5)[\text { ind/partner }]\end{array}$ & $10 \%$ & $60 \%$ & $7 \%$ & $22 \%$ & $\mathrm{n} / \mathrm{a}$ \\
\hline $\begin{array}{l}\text { Netherlands } \\
\text { (2009) }\end{array}$ & $\begin{array}{c}61 \% \\
(5)[\text { ind }]\end{array}$ & $6 \%$ & $42 \%$ & $10 \%$ & $42 \%$ & $\mathrm{n} / \mathrm{a}$ \\
\hline $\begin{array}{l}\text { N. Ireland } \\
(2005)\end{array}$ & $\begin{array}{c}36 \% \\
(3)[\text { ind }]\end{array}$ & $14 \%$ & $26 \%$ & $17 \%$ & $43 \%$ & $\mathrm{n} / \mathrm{a}$ \\
\hline $\begin{array}{l}\text { Scotland } \\
(1998)\end{array}$ & $\begin{array}{c}26 \% \\
\text { (5)[ind/partner] }\end{array}$ & $3 \%$ & $31 \%$ & $29 \%$ & $36 \%$ & $\mathrm{n} / \mathrm{a}$ \\
\hline
\end{tabular}

Sources: ABA, Legal Needs and Civil Justice: A Survey of Americans, Major Findings from the Comprehensive Legal Needs Study (1994); Ab Currie, The Legal Problems of Everyday Life: The Nature, Extent and Consequences of Justiciable Problems Experienced by Canadians (2007); Christie Coumarelos, Deborah Macourt, Julie People, Hugh M. McDonald, Zhigang Wei, Reiny Iriana \& Stephanie Ramsey, 7 Legal Australia-Wide Survey: Legal Need in Australia (2012); Hazel Genn, Paths to Justice: What People Do and Think about Going to Law (1999); Pascoe Pleasence, Nigel Balmer, Ash Patel, Andrew Cleary, Tom Huskinson \& Toby Cotton, Civil Justice in England and Wales: Report of Wave 1 of the English and Welsh Civil and Social Justice Panel Survey (2011); B.C.J. van Velthoven \& C.M. Klein Haarhuis, Paths to Justice in the Netherlands (2009); Tony Dignan, Northern Ireland Legal Needs Survey, Report prepared for Northern Ireland Legal Services Commission (2006); Hazel Genn, Paths to Justice Scotland (1999).

*N/A applies to countries that do not restrict the practice of law to bar-licensed lawyers, which the U.K. and the Netherlands do not. See discussion, infra.

U.S. National: phone survey supplemented by in-person of non-phone households.

U.S. State Average: Straight averages when data available from state surveys in Table 2; prevalence excludes AZ, $\mathrm{NJ}$; no action excludes TN; contact with lawyer is contact with lawyer or legal institution and excludes MA, NV, NY, TN, UT, VA, WI

Australia: phone; research purpose framed as "legal"; problem set included criminal which was second-most prevalent problem; contact with lawyer includes court personnel and community law centers; contact with other 
legal is estimated minimum; ${ }^{74}$ contact with non-legal provider is maximum, excluding estimated minimum of nonlegal advisers who gave legal advice.

Canada: phone survey; no action includes those who took no action due to perceived triviality of problemexcluding these, $17 \%$ took no action; non-legal includes informal; "alone or informally" is alone only.

England \& Wales 1997-98, Scotland, Northern Ireland: in-person survey; actions taken excludes those who took no action due to perceived triviality of problem.

England \& Wales 2010: in-person; other legal estimated by subtracting contacts with lawyers from total contacts with formal advisers.

Netherlands: Internet survey; allocation of contacts across lawyers, other legal and non-legal are estimates based on transition matrix.

There is, however, evidence that the rates at which Americans do nothing about their legal problems is high relative to these comparison countries. Certainly, none of these studies report "no action" rates anywhere close to the $50 \%$ range we see in some of the state surveys. But nor do these countries seem to reach rates in the $30 \%$ range that we see at the lower end in the state surveys and in the 1993 ABA national study. It is striking that the rates of no action picked up in several of these surveys-specifically those from the U.K. and from the Netherlands-are on the order of $5-10 \%$. This includes the $6 \%$ rate in the Dutch study-where the use of the Internet to conduct the survey might have been predicted, if anything, to have swept in more problems that people just didn't think were worth doing anything about. ${ }^{75}$ Even building in caution about difficulties comparing across different surveys, this seems substantially lower than the rates found in American studies. The rates observed in Canada and Australia also appear significantly lower than the ABA study and the lower rates in the state surveys, although the difference is not as striking and may be attributable to methodological differences.

\footnotetext{
${ }^{74}$ Minimum estimated by considering advice received from non-legal advisors when these are main advisor and using largest rate reported from: advice on legal rights or procedures; help with legal documents; help with court or tribunal proceedings or preparation; help with formal dispute resolution. See Christie Coumarelos, Deborah Macourt, Julie People, Hugh M. McDonald, Zhigang Wei, Reiny Iriana \& Stephanie Ramsey, 7 Legal Australia-Wide Survey: Legal Need in Australia, p. 130, Table 6.14 (2012).

${ }^{75}$ One concern with Internet surveys is that they can be biased because those who have Internet access may be a wealthier group or one with more resources to bring to bear on problems. In the Netherlands in 2011, for example, $94 \%$ of households had Internet access, the highest rate in Europe. Eurostat STAT/11/188, December 14 2011. In 2009, the year the Netherlands legal needs study was conducted, $90 \%$ of households had Internet access. Eurostat, Broadband and connectivity - households (code isoc_bde15b_h).
} 
Interpreting the significance of the numbers in Table 4 in terms of access to legal help is a bit more complex. First, given the multiple caveats about comparing data from different surveys and the variance across studies, Table 4 probably should not be interpreted to support a finding that Americans are more or less likely to handle their legal problems on their own or with only informal help from friends and family. It's possible the U.S. is low on this number, but we would need a much closer look to decide that. Second, there is no suggestion here that Americans contact lawyers about their legal problems more or less frequently than elsewhere. The rate of contact with a lawyer from the $1993 \mathrm{ABA}$ study is relatively high (27\%) - but quite comparable to what we see in England and Wales in 1997 and Scotland in 1998. The average from the U.S. state studies is significantly lower-14\%--but so, too, are the rates in all the other country studies conducted in the 2000s. Collectively, the evidence suggests that use of lawyers may have fallen in many places from the 1990 s to the 2000 s. We may think that $14 \%$--or even $27 \%$--is low relative to an ideal, but we cannot glean from the comparison with other countries that the U.S. is in a significantly different predicament.

There does seem to be support, however, for the possibility that Americans have access to less legal help overall than individuals in these comparison countries. First, we see that rates of selfrepresentation in settings where there is little choice about being in court are significantly lower in other countries than they are in the U.S. A 2004 study of family law cases in the U.K., for example, found that there was at least one self-represented litigant in $70 \%$ of adoption cases, $19 \%$ of cases involving financial matters such as child support and property orders, $61 \%$ of divorce cases, $33 \%$ of Children Act cases, and $28 \%$ of domestic cases involving restraining orders. ${ }^{76}$ In the Australian Family Court ${ }^{77} 17 \%$ of finalized

\footnotetext{
${ }^{76}$ Richard Moorhead \& Mark Sefton, Litigants in Person: Unrepresented litigants in first instance proceedings, 7, 31, Table 9 (2005). We categorize as "self-represented" those unrepresented litigants who were fully or partially active in the case. This excludes unrepresented parties who do not participate at all; this category in the U.S. is generally treated as a case of default and these litigants are generally excluded from counts of pro se litigants. ${ }^{77}$ The Family Court is a federal Australian court with jurisdiction over family and child support matters. This court does not have jurisdiction in the State of Western Australia.
} 
cases and $27 \%$ of trials had at least one self-represented litigant. ${ }^{78}$ A study in the Canadian province of British Columbia found that $11.5-24.6 \%$ of litigants were self-represented in family matters. ${ }^{79} \mathrm{~A} \mathrm{New}$ Zealand study from 2006-2007 found that at least one self-represented litigant was present in care of children cases roughly $35 \%$ of the time, domestic violence cases roughly $35 \%$ of the time, care and protection cases roughly $25 \%$ of the time, and dissolution, relationship property and other family matters less than $5 \%$ of the time. ${ }^{80}$ Although some of these numbers are high, they are still significantly below the percentages-some topping 95\%--reported in comparable American family law cases.

Finally, that Americans navigate the legal world with less legal help than in comparable countries is suggested by the data in Table 4 about help from legal providers other than lawyers. Looking at the American, English/Welsh and Scottish studies from the 1990s-with relatively high and comparable lawyer rates-we see that people in the U.S. appear significantly less likely to get legal help from non-lawyer providers. The same is true if we compare the average from the U.S. state studieswhere the "contact with lawyer" number includes other legal providers-and the other country studies conducted between 2000 and 2010. These other countries demonstrate significantly higher rates at which people seek out those who can provide legal help. To understand the numbers in Table 4, however, requires a better understanding of the scope of legal resources available to individuals in different countries. We turn to this now.

\section{Regulation of Legal Resources}

\footnotetext{
${ }^{78}$ Family Court of Australia, Annual Report 2011-2012. A 2002 study found that 31\% of litigants in contested cases at first instance were self-represented and $18 \%$ in appeal cases had been self-represented at some stage. E. Richardson, et al., Self-Represented Litigants: Literature Review, Australian Centre for Court and Justice System Innovation, at 25 (citing Rosemary Hunter, et al., The Changing Face of Litigation: Unrepresented Litigants in the Family Court of Australia (Research Report) Law and Justice Foundation (August 2002)).

${ }^{79}$ Id.; British Columbia Justice Review Task Force, Exploring Fundamental Change: A Compendium of Potential Justice System Reforms 23, n.15 (2002).

${ }^{80}$ Melissa Smith, Esther Banbury, and Su-Wuen Ong, Self-Represented Litigants: An Exploratory Study of Litigants in Person in the New Zealand Criminal Summary and Family Jurisdictions, 34, fig.1 (2009).
} 
Legal resources available to ordinary persons include lawyers and other providers of legal advice, the court system, and legal aid. The scope of legal resources in the U.S. is relatively narrow; the World Justice Report ranks the U.S. below the Netherlands, Germany, Sweden, the U.K, Australia, Canada, and France on access to civil justice. ${ }^{81}$ Currently, all U.S. states permit only licensed lawyers to practice law. ${ }^{82}$ The market for legal services is regulated by state bar associations, which impose qualitative restrictions on who may practice law and what the "practice of law" includes. ${ }^{83}$ State definitions of the "practice of law" generally include the provision of almost any legal service or advice, with limited exceptions in some consumer-service areas. ${ }^{84} \mathrm{An} A B A$ task force defined the "practice of law" as "the application of legal principles and judgment to the circumstances or objectives of another person or entity." 85 This definition suggests that the provision of all legal services in the U.S. is limited to licensed attorneys. Moreover, ethical rules in all states except the District of Columbia (which has modest exceptions) prohibit lawyers from providing legal services in organizations that are to any extent owned, managed or financed by non-lawyers; lawyers are also prohibited from entering into contractual arrangements with non-lawyers in any setting that can be interpreted to mean that the lawyer is splitting a fee with a non-lawyer. Lawyers must provide services directly to clients; they cannot be

\footnotetext{
${ }^{81}$ Mark David Agrast, Juan Carlos Botero, Joel Martinez, Alejandro Ponce, Christine S. Pratt, The World Justice Project: Rule of Law Index 2012-2013, 27, fig.1 (2013).

${ }^{82}$ This changed with Washington State's introduction in 2014 of a license for the (inartfully named) Limited License Legal Technician. See http://www.wsba.org/Licensing-and-Lawyer-Conduct/Admissions/Limited-Licenses-andSpecial-Programs/Non-Lawyers-and-Students/Legal-Technicians. New York is also looking to develop pilot programs for non-lawyer assistance in housing, consumer debt and elder law fields. See http://www.nycourts.gov/press/PDFs/PR13_07.pdf. In other states, non-lawyers may only serve as a scrivener, filling in a blank form on behalf of another person and providing general legal information. California and Arizona license legal document preparers but this licensing does not expand their powers beyond those generally available in states without specific licensing requirements.

${ }^{83}$ Gillian K. Hadfield, Legal Barriers to Innovation: The Growing Economic Cost of Professional Control of Corporate Legal Markets 60 Stan. L. Rev. 1689, 1706-1711.

${ }^{84}$ Id at 1706-1708. See also ABA, State Definitions of the Practice of Law, available at http://www.americanbar.org/groups/professional_responsibility/task_force_model_definition_practice_law.html (compilation of state definitions of practice of law).

${ }^{85}$ Hadfield, Legal Barriers to Innovation, at 1693, quoting ABA Task Force on the Model Definition of the Practice of Law, Report to the House of Delegates (Aug. 11, 2003), available at http://www.abanet.org/cpr/modeldef/recomm.pdf.
} 
employed to do legal work for the public by organizations (such as consumer associations) or

corporations. ${ }^{86}$ These restrictions prohibit lawyers from contracting with document or question-and-

answer web platforms or other service delivery mechanisms, such as retail stores or banks, for the

provision of legal help. ${ }^{87}$

Canada, Australia, and France also have relatively restrictive systems. Like the U.S., these countries prohibit anyone other than a bar-licensed lawyer from providing legal services, which include giving advice, drafting contracts, or assisting with the completion of documents. Anyone with a legal problem in these three countries is limited to the choice of finding and then paying for a private attorney, although Australia was the first jurisdiction in the world to permit non-lawyers to own legal practices. $^{88}$

The legal systems in many other countries are much more open, providing a broader range of sources for legal assistance. Finland, which has been characterized as the most open legal system ${ }^{89}$, does not restrict who can provide legal advice or represent others in court. ${ }^{90}$ Sweden maintains a comparably open system. ${ }^{91}$ Slightly more restrictive, but still quite open legal systems include the U.K. and the Netherlands, both of which reserve little other than representation in courts to licensed lawyers; there are no restrictions on who may provide legal advice. The U.K. permits non-lawyers to provide legal advice and licenses a variety of competing professional groups (including barristers, solicitors, legal

\footnotetext{
${ }^{86}$ There are some narrow exceptions: lawyers working for non-profit organizations can assist people with immigration matters pro bono; unions and political associations such as the NAACP are protected by the $14^{\text {th }}$ Amendment and may provide staff attorneys to assist their members; in some states (e.g. Texas) insurers may use staff attorneys to defend an insured under a policy that promises to pay legal costs of defense when there is no conflict of interest with the insurer. For a discussion see Gillian K. Hadfield "The Cost of Law: Promoting Access to Justice through the (Un)Corporate Practice of Law," 38 Int'l Rev. of Law and Econ. 43 (2014).

${ }^{87}$ See Hadfield, "The Cost of Law."

${ }^{88}$ See Christine Parker, Tahlia Gordon \& Steve Mark, Regulating Law Firm Ethics Management: An Empirical Assessment of an Innovation in Regulation of the Profession in New South Wales, 37 J. of L. \& Soc'y466 (2010). ${ }^{89}$ Paterson et al. (2003); SEO Economic Research, Regulation of the Legal Profession and Access to Law, at 61, t.3.8.

${ }^{90}$ Frank H. Stephen, The European Single Market and the Regulation of the Legal Profession: An Economic Analysis, 23 Managerial and Decision Economics 115, 116 (2002).

${ }^{91}$ Id.
} 
executives and licensed conveyancers) to perform most legal tasks. The Netherlands also has multiple legal providers, including non-lawyer legal professionals, legal insurers who provide legal assistance through staff lawyers or paralegals, social workers who have additional training in legal matters and are employed by larger cities and towns to provide advice to constituents, government networks of legal advisors operating as a legal "help desk" through offices, websites, chat systems, telephone and email advice, providing legal information, referrals to lawyers and up to 30 minutes of individualized advice; and student-staffed legal clinics operated independently of law schools but supervised by lawyers. The U.K. also permits legal services to be provided through non-lawyer owned organizations, including forprofit and non-profit corporate entities ${ }^{92}$, and does not place restrictions on what in the U.S. is called fee-sharing. One consequence of the more open regulatory regime is that there are increasingly robust online services available to provide one-on-one legal advice or assistance with legal matters such as filing for divorce or seeking a change in spousal or child support orders. ${ }^{93}$ In Germany, lawyers do not have a monopoly on legal representation; numerous persons and entities can represent clients in civil cases. ${ }^{94}$ In Hungary, lawyers do not have a monopoly on legal representation, even before a county court in civil matters, but only lawyers may represent clients in civil cases before appeals courts and the Supreme Court. ${ }^{95}$ In Poland, lawyers only have a monopoly on representation of criminal defendants; in civil cases, family members, joint participants, associations or trade unions may represent clients in court. $^{96}$

\footnotetext{
${ }^{92}$ Cooperative Legal Services, operated as part of the Cooperative Group, a consumer cooperative, for example, began operation in 2006. It was one of the first three entities licensed to provide legal services as what the U.K. regulatory scheme calls an alternative business structure (an organization or corporation other than a traditional law firm partnership) in 2012. Prior to that licensing, it could not provide access to solicitors, but it could provide assistance with legal advice, completion of documents and do-it-yourself support for legal actions.

${ }^{93}$ See Hadfield "The Cost of Law" and Gillian K. Hadfield "Innovating to Improve Access: Changing the Way Courts Regulate Legal Markets" 143 Daedalus 83 (2014) for more discussion.

${ }^{94}$ European Commission for the Efficiency of Justice, Scheme for Evaluating Judicial Systems 2011, Germany, 7576.

${ }^{95}$ Id., Hungary, 72-73.

${ }^{96}$ Id., Poland, 36.
} 
There are also differences in the types of financial assistance available to ordinary individuals seeking legal services. Most countries have some form of legal aid, usually with income cutoffs to determine eligibility. Some countries provide loans or insurance for legal expenses. For instance, Germany provides loans to low-income individuals for legal aid services. While the loans are required to be repaid if the borrower is financially able to do so, in practice loans are repaid only $15 \%$ of the time. ${ }^{97}$ Sweden's legal system offers legal expense insurance instead of legal aid and $97 \%$ of residents have addon legal expense insurance. Seventy-five percent of Finns have a legal expense insurance policy ${ }^{98}$; Finland provides legal aid in addition. $40 \%$ of Dutch households have legal insurance, at a cost of approximately $€ 250$, which provides access to staff lawyers or paralegals (although often excludes family and criminal matters.)

This comparison adds to our understanding of the legal needs surveys discussed in the previous section. In reporting the data on contact with legal providers in Table 4, we distinguished between lawyers and others authorized to provide legal assistance. In the U.S., there really are no other entities besides lawyers authorized to provide legal assistance; this category in the 1993 ABA study largely refers to contact with courts. But in countries with much less restrictive systems such as the Netherlands and the U.K., any formal advisor is potentially a source of legal advice; we noted in Table 4 that there really is no category of formal advisors who are not authorized to provide legal help. ${ }^{99}$ These non-lawyer sources of legal assistance play a substantial role in raising the rates at which citizens in these countries enjoy some legal help in dealing with legal problems above those we see in the U.S. despite the fact that rates of assistance from a lawyer do not appear to differ.

The apparently greater access to diverse sources of legal help in the U.K. and the Netherlands may also provide insight into the rates at which people lump their problems rather than try to deal with

\footnotetext{
${ }^{97}$ SEO Economic Research, Regulation of the Legal Profession and Access to Law, at 45.

${ }^{98}$ Id. at 45-46.

${ }^{99}$ This does not mean that all contacts with formal advisors resulted in legal assistance.
} 
them. Table 4 indicates that the lowest rates of "no action" are found in the Netherlands and the countries of the U.K. In these countries, people with legal problems are not faced with the stark choice between locating an affordable lawyer, doing nothing or going it alone. They can also turn to the volunteer-staffed Community Advice Bureaux, government networks of legal help desks, online services, insurers, banks, grocery stores, unions, consumer organizations and more. It seems quite possible that this range of options makes a strategy for action both more visible and more accessible, woven more securely into everyday settings and forms of interaction.

Also on this line of reasoning, what is currently reported as self-help-acting on one's own or with help only from friends and family and not a formal advisor-may also be indicative of a more generous legal resource landscape. The high rate of self-help in the 2010 England and Wales survey is particularly intriguing here. On the one hand, it may indicate a failure of the legal environment relative to 1997 - and certainly access to legal aid during this period has been significantly cut back. ${ }^{100}$ It may, as the researchers suggest, reflect only the fact that the 2010 survey asked about all problems, not only those that were difficult to solve-potentially sweeping in a larger number of problems that were in fact amenable to self-help (although this seems inadequate to explain the 25 point increase in self-help). But the increase in self-help may also reflect the changing landscape in the U.K., with more resources available for self-helpers. Many of these services may not have been reported as consultation with an adviser; and the survey design does not appear to solicit information about whether people used, for example, an online or retail service for help answering questions about legal rights and procedures, filing for a "d-i-y" ("do-it-yourself") divorce, preparing a will or navigating probate.

The question we want to raise then is this: are the apparently higher rates at which we see Americans lumping their problems in the $A B A$ and state surveys a consequence of the more restrictive scope of legal help available to them? Or are they just evidence that although Americans may be facing

${ }^{100}$ See Roger Smith, After the Act: What Future for Legal Aid?, Justice Tom Sargant Memorial Annual Lecture 2012, 3 (Oct. 16, 2012). 
on average two or more justiciable problems in a year they simply choose not to do anything about them, despite having reasonable options to respond?

We need to be cautious here because simple differences in rates alone are not enough to support an inference of something more fundamentally different in these legal settings given the differences in the survey and reporting methods. The surveys from England, Wales and Scotland, which report the lowest rates of "no action," exclude from the denominator cases in which the respondent says he or she took no action because the problem wasn't important enough. The researchers take care to document in those reports ${ }^{101}$, the impact of what they call the "triviality threshold" is very small. ${ }^{102}$ Nonetheless, given the absence of careful cross-national studies, it is impossible to say whether or not there is a causal relationship between the legal resource landscape and the rates at which people take no action on their problems or deal with them on their own is correct. Clearly the data suggest that the rate at which Americans lump their problems cannot easily be written off to triviality or choice. Instead the data should be interpreted as a potentially important indicator of the paucity of options available for resolving legal issues.

\section{Conclusion}

American society is often seen as emblematic of the rule of law and its adversarial legalism makes it a particularly dense legal environment. But the evidence presented above about Americans' experiences with the legal system and the availability of legal resources paints a different picture than that envisioned by a highly law-based society. The evidence is suggestive only. The data that we have reviewed does not control for the nature of legal problems, the opportunity for problems to be resolved in less litigious ways and the resources necessary to achieve that goal. The thinness of the available data

\footnotetext{
${ }^{101}$ Genn Paths to Justice at 37; Genn \& Paterson Paths to Justice Scotland at 50

${ }^{102}$ Notably, the survey methodology in England \& Wales was changed with the 2010 survey, eliminating the triviality threshold. Moreover, the survey questions in 2010 only asked about "problems" and not, as in the original Genn approach used in 1997, problems that were "difficult to solve." Here we do see an increase in the no action rate in England \& Wales-from 5\% to 10\%-between 1997 and 2010, but not a major leap upwards.
} 
simply do not allow for such careful comparison, although they clearly suggest the need for such a study to be conducted.

The results, as rough and ready as they are, nonetheless do present a serious challenge to the American legal profession, which has, for the last 100 years, claimed exclusive authority to regulate the entire legal system in the U.S. ${ }^{103}$ The profession's assertion of regulatory authority has arguably blocked the capacity for federal or state regulatory or policy responses to the crises in U.S. legal systems.

What accounts for the significantly lower level of legal resources-public expenditure, legal aid, judges and (for Germany and the U.K.) lawyers-available at the macro level in the U.S. as compared to other advanced market democracies? For the more than $50 \%$ decline over the past fifteen years in the total effective number of hours of legal services per household per problem? For the more than $50 \%$ drop in the use of lawyers' services by the poor in addressing their problems in the decade since the 1993 ABA study? The lack of systematic data makes causal analysis difficult and speculative. Clearly we need substantially more attention to detailed study of the nature of legal systems and how they shape and meet the demand for legal services. In this concluding section we offer some preliminary thoughts on how those studies should be framed.

The access problems in the U.S. legal system are largely conceptualized by the profession as problems of the ethical commitments of individual lawyers to assist the poor and the failure of federal and state bodies to provide adequate levels of funding to legal aid agencies and the courts. The first conceptualization fails, we believe, to come to grips with the dimensions of the problem, which cannot be solved with an increase in pro bono efforts, as welcome as such an increase would be. Pro bono currently accounts for less than $2 \%$ of legal effort in the country. Even if every lawyer in the country did

\footnotetext{
${ }^{103}$ See Thomas M. Alpert The Inherent Power of the Courts to Regulate the Practice of Law: An Historical Analysis. 32 Buff. L. Rev.525 (1983); Hadfield, Legal Barriers to Innovation, 1696-1701 (2008); Hadfield, The Cost of Law $<$ does this need a fuller cite? It's cited above more fully.
} 
100 more hours a year of pro bono work, this would amount to an extra twenty-five minutes per U.S. person a year, or about thirty minutes per dispute-related (potentially litigation-related) problem per household using the average number of legal problems reported in the state legal needs surveys. This does not even begin to address the realistic demands that ordinary households have for ex ante assistance with navigating the law-thick world in which they live, some of which could reduce the need for ex post legal representation in litigation and crisis.

The problem is not a problem of the ethical commitment of lawyers to help the poor. Nor is an increase in public legal aid likely to make a substantial impact. The cost of just one extra hour of legal aid on each dispute-related problem per household would be on the order of $\$ 70$ billion annually at a market rate of $\$ 263$ per hour. ${ }^{104}$ Even if we thought we could find enough lawyers willing to supply that help at \$150 an hour, this level of assistance would entail a more than ten-fold increase in current U.S. levels of public and private (charitable) legal aid funding. Again, more legal aid funding would be welcome and is clearly called for, but it cannot make a serious dent in the nature of the problem.

So what is the problem? The bits of data we can see in the comparative analyses are suggestive of an important role for the regulatory and policymaking structure governing legal markets in the U.S. The U.S. stands largely alone in the world in terms of the extraordinary extent to which the bar and judiciary wield exclusive authority for shaping the cost and market structure of legal goods and services. Some of this difference can be seen to come from the structure of the courts and legal profession as elements of the civil service bureaucracy in countries such as Germany and France. This way of structuring courts and delivering legal services locates policy and funding decisions squarely within a government agency. In addition, civil law systems emphasize a much broader role for the judge, as opposed to parties and their lawyers, in the conduct of litigation. This arguably accounts for the

\footnotetext{
${ }^{104}$ Average calculated from Altman-Weil data for lawyers working in solo or small firm (fewer than 24 lawyers) practice in 2012. See supra note 19. We are using here an estimate that there are approximately 130 million in the U.S. and taking the average number of problems per household (2) reported in the state legal needs surveys.
} 
substantially higher allocation of resources to the court systems in Germany, with many more judges per case. But the U.K. is a powerful counterexample to the hypothesis that we are seeing a difference between common law and civil code systems. The U.K. clearly devotes substantially more resources to the provision of legal services to ordinary citizens, measured in terms of public expenditure, legal aid or judges per 'case', even though the U.K. follows the common law practice of much greater reliance on the adversarial resources of parties to structure litigation. What explains this?

The importance of investigating with careful empirical studies the hypothesis that the regulatory system accounts for the failure of the U.S. legal system to provide an adequate level of legal inputs for ordinary people becomes even more apparent when the data from the Netherlands, which has a comparably open system allowing many non-lawyer service providers, is viewed alongside that of the U.K. The striking difference in the rate at which people do nothing in response to legal difficulties between the U.S. $\left(29 \%\right.$ or higher $\left.{ }^{105}\right)$ and the U.K. $(10 \%)$ and The Netherlands $(6 \%)$ is highly suggestive of the role that a robust system of legal inputs plays in making a legal system a real, rather than apparent, basis on which everyday lives are structured. A careful study of how different regulatory regimes influence not only the use of legal resources in resolving problems once they have erupted but also the use of these resources ex ante to decide what transactions and relationships to enter into, leave, modify and so on is clearly called for by these results.

Those concerned with access to justice have long emphasized how the extreme approach to unauthorized practice of law in the United States drastically curtails the potential for ordinary folks to obtain assistance with their law-related needs and problems. Key contributions have been made in this regard by Deborah Rhode ${ }^{106}$, David Luban ${ }^{107}$ and Barlow Christensen. ${ }^{108}$ American lawyers often take for

\footnotetext{
${ }^{105} 29 \%$ is the figure from the ABA study; the state legal needs surveys report rates ranging from $21 \%$ to $53 \%$.

${ }^{106}$ Deborah L. Rhode,Policing the Professional Monopoly: A Constitutional and Empirical Analysis of Unauthorized Practice Prohibitions, 34 Stan. L. Rev. 1 (1981); Rhode, Professionalism in Perspective: Alternative Approaches to Non-Lawyer Practice, $1 \mathrm{~J}$. Inst. For Study Legal Ethics 197 (1996); Rhode, In the Interests of Justice: Reforming the Legal Profession (2003); Rhode, Access to Justice (2004).
} 
granted that it is natural that anyone who wishes to practice law must be an authorized member of a bar association and subject to the admissions, ethical and disciplinary controls of the profession, including the judiciary. The regulatory problem, however, goes beyond a straightforward restriction on supply. The more fundamental problem with the existing regulatory structure is traceable to the fact that the American legal profession is a politically unaccountable regulator, which lacks the funding levers and policymaking apparatus needed for a sector that is a huge share of the American economy and one that plays an increasingly important role in a rapidly changing and decentralized economic system.

The problem is one of urgent need for structural reform in the regulatory and policy/funding system responsible for the critical infrastructure of market democracy, particularly one that draws as heavily as the American system does on law and legalism to structure economic, political and social relationships. We hope this chapter helps paint a clearer picture of the legal needs of and legal resources available to ordinary people. With a better grasp on the dimensions of the problem, we hope it can be more readily tackled.

${ }^{107}$ David Luban Lawyers and Justice: An Ethical Study (1988).

${ }^{108}$ Christensen, The Unauthorized Practice of law: Do Good Fences Really make Good Neighbors-or Even Good Sense?, 1980 Am. B. Found. Res. J. 159 (1980) 